European journal of American studies

Special Issue: Women in the USA

\title{
Domestic Wounds: Nursing in Louisa May Alcott's War tales
}

Daniela Daniele

\section{(2) OpenEdition \\ Journals}

Electronic version

URL: https://journals.openedition.org/ejas/10747

DOI: 10.4000/ejas. 10747

ISSN: 1991-9336

Publisher

European Association for American Studies

\section{Electronic reference}

Daniela Daniele, "Domestic Wounds: Nursing in Louisa May Alcott's War tales", European journal of American studies [Online], 10-1 | 2015, document 2.4, Online since 31 March 2015, connection on 08 July 2021. URL: http://journals.openedition.org/ejas/10747 ; DOI: https://doi.org/10.4000/ejas.10747

This text was automatically generated on 8 July 2021 .

Creative Commons License 


\title{
Domestic Wounds: Nursing in Louisa May Alcott's War tales
}

\author{
Daniela Daniele
}

\section{Yankee Matrons and Deaconess Dix}

1 In her early war tales, Louisa May Alcott adopted humor and satire to represent the grim realities of the Civil War. That brotherly fight constrained women in auxiliary roles but also introduced a growing army of charitable ladies to a new style of nursing that served to consolidate them as active agents of reform. As nurses in the fields, they left their homes and families to bring domestic values inherited by their "Republican mothers" to the war. Appointed by the Superintendent Dorothea L. Dix, Louisa May Alcott worked in an army hospital of Germantown (Washington, D.C.) for six long months, taking care of wounded soldiers until typhoid fever forced her to return to Concord. Before quitting, she studied how to cure injuries with the help of manuals such as Gun Shot Wounds by Doctor Home, often written by women who circulated the new nursing techniques inspired by Florence Nightingale's Notes on Nursing (1860). Her recruitment into the Union army is fully documented by her neighbor Sophia Hawthorne, who, in a letter to her daughter Una, refers to the soldier "Louisa Alcott" going to Fredericksburg, that is, "to the very mouth of the war." In the semiautobiographical account of her nursing experience, when her sister urges her to marry, the narrator replies: "Can't afford expensive luxuries, Mrs. Coobiddy" (Hospital Sketches 3).

2 Alcott took her place in the Union Hospital at Georgetown where for six weeks she worked untiringly under trying conditions. At the Union Hotel Hospital, she cured the casualties of Fredericksburg and based her Hospital Sketches on her letters home, "written on inverted tin kettles, in my pantry, while waiting for gruel to warm or poultices to cool, for boys to wake and be tormented, on stairs, in window seats \& other sequestered spots favorable to literary inspiration" (Letter home of November 6, 1863 in The Selected Letters 95). In this endeavor she was also sustained by the daily reports 
she handed in to her Superintendents, according to the protocol established by Florence Nightingale. Those letters and reports have not survived in the original form but were re-elaborated by the writer in a first-person narrative that the abolitionist/ philanthropist Frank Sanborn published in the Boston Commonwealth between May and June 1863. The tome was much praised by Sergeant Garth Wilkinson James-one of Henry James, Sr.'s sons - and by William Dean Howells, Consul in Venice, who sent his support and congratulated Nurse Tribulation Periwinkle. On August 28, 1863, Hospital Sketches was reprinted in book form by the abolitionist/reformer James Redpath in the series of Civil War fiction "Camp and Fireside Stories," mostly meant to entertain the troops and to inform their relatives about camp life. Unusually associated with the army, bouts of homesickness appear in the tale "On Picket Duty" (1864), revealing the personal defeats and emotions of the soldiers and making the thought of their sweethearts oddly overlap with the realities of war: "I don't know where she is, and camp is all I've got" (On Picket Duty and Other Tales 14). No wonder that the cover illustration chosen by Redpath for each volume issued featured a picket of soldiers wrapped up in heavy coats and sitting on a box full of weapons, intently listening to their comrades' stories before the fire in an interesting interplay of domesticity and camp life. The royalties from Louisa's book were devoted to war orphans and, after its unexpected success, Louisa collected more Civil War tales in On Picket Duty and Other Tales. Roberts eventually republished Hospital Sketches and the 1869 volume Hospital Sketches and Camp and Fireside Stories.

3 The hard but successful acquisition of a public role during the conflict had a large social cost for those women, whose austere, matronly clothes instantly turned them into queer mothers for the wounded soldiers temporarily alienated from their family care and affection. Nurses were recognized for the sober conduct and professional attitude as "mothers of the nation." They were meant to unconditionally dispense care and affection, industriously repressing any form of emotional relief, perceived as emancipated "singles" deprived of any seducing and "womanly" features. Dedication and self-control defined this philanthropic category of virtuous spinsters, depicted in Hospital Sketches as women with a sad past: "the new 'nuss,' who suffered untold agonies, but concealed them under as matronly an aspect as a spinster could assume" (26). In their auxiliary functions in the army, only middle-aged and single women "plain in appearance" were hired. Mature and well-referenced women had to be at least thirty and soberly dressed with undecorated skirts (Massey 46), according to the strict standard enforced by Dix and the General Surgeon for nurses who were required to look perfectly healthy and very plain in their personal appearance. Not meant to maintain a definite role in the Victorian family, in wartime they created a contingent "home" of affection and care inevitably disrupted by the soldiers' eventual return home to their actual families. As her biographer recalls, Dix called for volunteers "who are sober, earnest, self-sacrificing, and self-sustained; who can bear the presence of suffering and exercise entire self-control, of speech and manner; who can be calm, gentle, quiet, active, and steadfast in duty, also who are willing to take and to execute the directions of the surgeons of the divisions in which they are stationed." In the same letter to Louisa Lee Schuyler of April 29, 1861, she clarified that "No young ladies should be sent at all" (qtd. in Brown 281), presumably unaware that not only married women or mature, sensible spinsters were selected, as the indulgent mediation of her mother allowed Louisa to join the army on December 11, 1862. According to the 
regulations, nurses had to accurately hide their female traits and deal with soldiers with "manful cheerfulness" in promiscuous conditions (Hospital Sketches 339). In a health system dominated by male medical doctors, the women selected by the Sanitary Committee had to prove a passionless modesty impermeable to the gallant attentions of their patients. Dorothea Dix was certainly among these austere Amazons, and depicted as quite despotic in Hospital Sketches ${ }^{2}$ in her Spartan conduct and neutral clothes, and wrapped up in rigid uniforms ${ }^{3}$ no different from the military style suggested by Eliza Pollard in her portrait of Florence Nightingale:

No deaconess was to be under twenty-five years of age. Their dress had to be simple but not unbecoming, a blue cotton gown, white apron, collar and muslin cap, without any peculiarity of shape; it has the great advantage, that out of doors it attracts no particular attention to the wearer. (35-36)

4 The sober attire and discipline required by nurses forces the semi-autobiographical Nurse Periwinkle to repress her natural attraction to the injured male bodies that she was daily required to wash and dress. Any "little romance" ${ }^{4}$ was grimly quenched by the moral imperatives of her public display of maternal duties and patriotic ideals. ${ }^{5}$ Diminished by a commitment starkly different from the one performed by the mothers and sweethearts, who were periodically allowed to comfort their loved ones in the wards, Tribulation Periwinkle found a satirical way of denouncing this repression of instincts when she claimed, "though belonging to the sisterhood of 'ministering angels', I had no wings" (42). Unable to share any authentic intimacy with her beloved other patients, she kept sitting adjacent to her favorite patients, engaging a mute rivalry with the fiancée who would replace her next to them: "the dearest Jane filling my place, tending the wounds I tended, brushing the curly jungle I brushed, loving the excellent little youth I loved, and eventually walking altarward, with the Sergeant stumping gallantly at her side" (89).

5 In the same line, Jo March, who cannot bear her sister Meg's departure after marriage, could well understand Nurse Periwinkle when she exclaimed: "I never liked this breaking-up of my little household" (89). Generally inclined to create a climate of psychological support in war hospitals, in their workplace nurses were used to all kinds of healing and the manipulation of injured bodies, in circumstances quite peculiar for Victorian singles. As maternal, mature rescuers, the increasing emasculation of soldiers in hospital wards grew parallel with the gradual empowerment and self-reliance of these female workers who daily confronted strict moral codes that required them to be indifferent to the latent eroticism and calls of male sensuality expressed by those wounded bodies. ${ }^{6}$

6 After all, by entering the army as a war nurse, Alcott was expected to exercise a high form of pietistic Christianity. Her experiences led her to the publication of the first book published under her name, which conveyed, in Nightingale's style, all the "tribulations" and homely values related to her efforts to bring a domestic atmosphere in that distraught sanitary establishment (35). As Brown points out in Dix's biography, when the Civil War started, "The Lady with the Lamp" "would not merely tend to soldiers; she would help to heal the nation" (274). This epic figure was celebrated in countless panegyrics and represented in her midnight vigilance over the sick and wounded troops in the Crimean War, becoming "virtually synonymous with the idea of nursing by 1861," and widely credited with opening the first major field of career 
opportunities for women (274-75). Dix's achievements during the Civil War and her idea of nursing as a calling specifically for women were comparable to Florence Nightingale's. She failed to meet her, but she visited her famous hospital in Scutari and was inspired by the compassionate principles which also spread among male volunteers. (Hospital Sketches was published three years before Drum-Taps but already conveyed the overt sensuality of the wounded male bodies rubbed by the nurses recruited for the first time in public roles of care.) The wards were conceived as a home where women's motherly role was considered natural to women, in spite of Tribulation's claim: "I am naturally irascible" (9). The combination of male, managerial and therapeutic abilities designed to heal America from its internal divisions, and the physical and moral scars produced in the nation's body, the conflict required Alcott to adopt a satiric mixture of humor and sentiment to represent an environment in which the "[c]urious contrasts of the tragic and comic met one everywhere" (34).

7 The war hospital, interestingly described as a home suspended between the public and private sphere, was a social and intimate environment able to reflect, as Young suggests, the topsy-turviness of Alcott's heroines $(22,70)$. In this respect, even Little Women could be read as a war narrative in which Alcott's restless alter-ego is always at war with "the bosom enemy" (Little Women 9) and reflects the troubled circumstances of domestic order to be restored. The emblematic reference to the "March" in her very last name partakes of a military rhetoric that enters, along with her defiant selfreliance, Jo's jargon, as she laments that during wartime "keeping her temper at home was a much harder task than facing a rebel or two down South" (8). Although during the Civil War, a few women cross-dressed to fight like spies and male soldiers, Alcott's ambition went unfulfilled: “I can't get over my disappointment in not being a boy, and it's worse than ever now, for I'm dying to go and fight with papa and can only stay at home and knit, like a poky old woman" (5). This sharp, vibrant style in Little Women became a distinctive stylistic feature of Alcott's narratives, and even Meg, who lacks much of her sister's stamina, confesses to her fiancé her desire to be a soldier, since "it is hard to be at home when men are at war" (109). Jo's generous gesture of cutting her beautiful black hair to pay for her mother's journey to the front to rescue her injured husband is another allegory of the physical mutilation of her femininity. ${ }^{7}$ In her real life, as a regretful soldier-manqué, Alcott, in April 1861, wrote in her journal, "I've often longed to see a war, and now I have my wish. I long to be a man; but as I can't fight, I will content myself with working for those who can" (Journals, 105).

8 As for Alcott, her first initiative during the war was sewing soldiers' uniforms and knitting socks for the troops, while spinning sensational tales, as she reported in her diary: "between blue flannel jackets for 'our boys' and dainty slips for (niece and nephews) Louisa Caroline or John B., Jr. [...] I reel off my 'thrilling' tales, and mess up my work in a queer but interesting way" (September-October 1862, 109). Later on, with the charm of her tragi-comic writing, she stressed the many uses of domestic culture during the conflict and, in Hospital Sketches, she re-elaborated the story of her nursing service, starting with her picaresque heroine who strides in the muddy streets of the capital, turned "military at once, called my dinner my rations, saluted all new comers, and ordered a dress parade" (5).

9 In Hospital Sketches, Tribulation immediately points to the flaws in the bureaucratic machinery which slowed women's access to the profession, arguing that the assistance 
of female nurses, generally unacquainted with the impersonal codes of the public sphere, was further prevented by the rigid work division which saw them employed in subaltern roles of medical care, apart from the few adventurous ones who opperated as surgeons. The rivalry between pragmatic physicians and charitable nurses is well represented in Alcott's war tales, in an environment usually indifferent to human pain despite the success of the healing policies reformed by Nightingale and Dix. Both considered nurses no mere assistants to physicians but coordinators of a more powerful and effective form of care aimed to re-establish the moral "sense of harmony" disturbed by illness, starting from the motherly and "curative powers" of nurses. Upon the publication in the United States of the best-seller Notes on Nursing. What It Is and What It is Not (1860), Nightingale clarified that "nurses embodied the curative power of the milieu-whether it was a home or a hospital-by supervising ventilation, light, noise, cleanliness, and diet for their patients.They were first and foremost moral guardians" (qtd. in Brown 275). In a time in which sterilization was ignored, cleaner hospitals reduced the risks of tetatus and gangrene. Although nursing was considered a suitable vocation for women, male workers in the field were prejudiced against them on the grounds that, as Clara Barton made clear, any form of public work aimed at the public health was too hard and degrading for women (qtd. in Massey 51). Despite their proverbial modesty and strong sense of discipline, the American followers of Florence Nightingale were exposed to the boycott of medical doctors, ${ }^{8}$ usually resistant to the innovations introduced by the rigorous Superintendents wearing a shawl and a Quaker hat who were appointed by the Sanitary Commission to lead the Army Nurse Corps. ${ }^{9}$ These scornful doctors were often poorly trained and superficial in their medical practice. Wardmasters were no better and used to overdose mutilated patients with opium pills and laudanum, as they did to Alcott, when she entered a delirium while sick with typhoid fever due to unhealthy conditions in the hospital. ${ }^{10}$ Dix herself fought doctors in camps for respect, and nurses even competed in their exemplary dedication and altruism with ministers, who felt threatened, no less than surgeons and physicians, by this female interference in their own moral sphere (Massey 377). It is not by chance that Nurse Superintendents were called "deaconesses," as ministers of a moral and physical cult (Massey 43-47). "Deaconesses" - as a sacerdotal expression of the "feminization" of the American society - showed that in medical care moral attitudes were more powerful than ministers' sermons. And in Hospital Sketches, Tribulation observes that, in terms of authority, the initials of Dorothea Dix could easily stand for Doctor of Divinity (a title previously adopted only for the transcendentalist erudite Elizabeth Peabody), given the spiritual relevance of her work in her patients' eyes. ${ }^{11}$

10 In comparison, the nursing model established by Alcott in Hospital Sketches confirms the domestic emergence in the hospital wards of a model of Yankee matron likely to restore order in the national family. A former governess of Ellery Channing and a writer of children's literature herself, whose chapbooks in the Twenties were recommended by Sarah Hale, ${ }^{12}$ Dix was a correspondent of reformers like Caroline Dall and Anna Jameson, who had been associated with the transcendentalist circle. Dix, who was considered an "unbearably zealous" reformer by Alcott, traveled to Europe with Jameson to learn Catholic models of sanitary management. ${ }^{13}$ In their efforts to combat the inefficiencies of the medical system, these women gradually modified methods and regulations, often in conflict with the surgeons in charge. ${ }^{14}$ 
11 Alcott appropriated the ancillary poses of the pious Victorian matriarchs that her readers associated with diligent custodial endeavors, emphasizing her female nurses' abnegation and sobriety, especially as mediators of the domestic, racial, and regional conflicts which entered hospital wards. These places of healing were also chaotic war sites in which Yankee and Black mothers searched for missing soldiers and contrabands, celebrated by Alcott in neoclassical fashion. ${ }^{15}$ In "Love and Loyalty," an old lady enters the army in the role of nurse to trace her lost sons. Inspecting wounded soldiers in hospital beds and stretchers, she hopes to recognize her boys starting from the hair lock or the little portrait of their mother that they carried with them. After all, in line with the reforming project of Florence Nightingale, Alcott represents the hospital as a cozy substitute for home, whose therapeutic functions were enhanced by the soothing and maternal presence of female nurses as a valid alternative to the doctors' impersonal and often abrupt medical practices. ${ }^{16}$ Hence her insistence on the importance of their moral support in treatments and of the nurses' power of compassion to balance the crudity of physicians. The new domestic protocols of cure involved a sense of affection and intimacy which added to the ease and comfort of a properly aired environment. In these warm hospital interiors, soldiers confide to each other their deepest emotions and frustrations: "In the silence, each shaped for himself that vision of home that brightens so many camp-fires [...]. 'Tellin' how we found our wives wouldn't be a bad game, would it, Phil?"" ("On Picket Duty" 5). As Douglas writes, even at the front, women opened a new branch of the American Home and their philanthropic and humanitarian commitment left permanent signs in the sanitary institutions and in the restoration of a state torn by war. ${ }^{17}$ In "A Hospital Christmas," Alcott vindicates the female reform of dilapidated public structures, hinting at the specific strategies which made them more dynamic and manageable, thanks to the feminine power of sentiment and solidarity: "A hospital ward is often a small republic, beautifully governed by pity, patience, and the mutual sympathy which lessens mutual suffering" (Camp 325).

12 As a convinced advocate of Lincoln's cause and the daughter of one of the conspirators which in 1859 supported John Brown's failed assault on the arsenal of Harpers Ferry in Virginia, Louisa May Alcott does not fail to use her war stories to declare her abolitionism. In Hospital Sketches, the disorder of the "Hurlyburly House" (84) refers to the state of chaos produced by war that the writer conveys by humorously alternating didactic, sentimental, and thrilling tones, while addressing all her sympathy for the wounded troops. As she moves from one ward to another, Tribulation Periwinkle sees each of them dominated by a specific humor, in a variety of tones which aptly situates the book in the tragi-comic genre of the Dickensian sketch. Alcott stresses this variety of tones, also typical of the Victorian stage, by saying,

I had managed to sort out the patients in such a way that I had what I called 'my duty room', 'my pleasure room' and my 'pathetic room', and worked for it in a different way. One, I visited, armed with a dressing tray full of rollers, plasters, and pins; another, with books, flowers, games, and gossip; a third, with teapots, lullabies, consolation, and, sometimes, a shroud. (41)

13 Her hospital scenes are sustained by the interplay of laughter and compassion, aiming to entertain the readers with the pathetic celebration of wounded heroes and the suffragist pride of the nursing narrator. Nevertheless, a number of conservative readers objected to the light tone and the amused irony of this fictional account of her 
nursing service, requiring more sentimentalism and display of "wounds of the heart" than Alcott could provide. Bigots reacted to her charming accounts of her war experience by asking petulant questions: "Are there no services by hospital death-beds, or on Sundays?" (80). And, in her lucid epilogue to the second edition of the book, Alcott replied that her religious convictions did not allow her to privilege a specific Christian practice since the modest aim of her sketches was sending home amusing accounts of her life in a hospital camp, with the many benefits and therapeutic effects of a good laugh. ${ }^{18}$ In her lively war reportage, Alcott not only insisted on the long agonies of exemplary masculine characters, choosing to alternate the Christian patience and sentimentalism of the "pathetic room" with moments of relief in which her patients were re-baptized according to their pathologies and mutilations. ${ }^{19} \mathrm{The}$ tragic-comic irreverence of this metonymic reduction of injured individuals to their wounded parts still challenges our politically correct habit of paraphrasing disabilities and impairment, but Alcott insisted upon the sadistic roots of her comic effects as a way of escaping the commonplaces of the patriotic rhetoric which surrounded the Union army.

14Alcott's early hospital scenes were only the first portrait of the artist as a nurse. More nurse stories soon followed: "My Contraband," initially titled "The Brothers,"20 moves the autobiographical perspective from the picaresque Tribulation to the mature Faith Dane: the solitary and shrewd spinster introduced in Moods, who becomes a model of strength and solitary rectitude, as a compassionate advisor always willing to listen to her neighbors' family drama, but never personally involved in matrimonial dynamics. She appears in "My Contraband," as the wise nurse who prevents the fratricide of her mulatto assistant raised on the same Southern plantation with his wounded white brother. In her proto-feminist features, Faith Dane concentrates the frustrated aspirations of the romantic, willful women who actively participate in warfare in the only available model of female emancipation: that of the austere, dignified and solitary Amazon. Miss Dane's last name is voluntarily adopted by her mulatto assistant whose restlessness anticipates the features of the heroic "Dan" in Jo's Boys: a late narrative in which the writer's sympathies (and that of her alter-ego of Jo March) are all with her naughtiest pupil. Gradually "tamed" as the famous "children's friend," Faith Dane, like Alcott herself, modestly keeps her emotions to herself.

15 "Nellie's Hospital" is the miniaturized adaptation of her nursing chores as a child's game (1864, rpt. in Elbert 29-40) inspired by her convalescent brother to a girl who attends to a number of animals, birds and insects, like the "contraband" fly that she frees from a spider's web and treats with disciplined dedication. "A Hospital Christmas" (1864, Hospital 317-44), "The Blue and the Gray" (1868, 295-319), "Love and Loyalty" (1864-200-56) complete the nursing narrative series, along with Alcott's clear homage to Nightingale, "The Hospital Lamp," ${ }^{21}$ whose soothing light shines upon the two injured protagonists as "a comfortable gleam upon some anxious thought" (104). And since by becoming a nurse Alcott had initially meant to join the battle, many of these tales also report acts of heroism in the battlefield by brave soldiers like Absalom Tonser in "The Hospital Lamp," who recalls, as the nurse "paused to wet the stump of the leg left at Fredericksburg" (104), the most dramatic sequences of his fights, providing sensational glimpses of war action long before Stephen Crane's turbulent battle scenes. In this way, readers witness all the horrors of the battle scenes as Alcott displays "through the smoke of the battles" (11), "battle-corpses, myriads of them," "debris and 
debris of all dead soldiers" (11), in passages which anticipate the dirges that Whitman will devote to the injured veterans. Printed in Washington in 1865-66, Whitman's book seems to convey in verses Alcott's story of the two Union soldiers who keep hearing the roar of the battle in their ears, "laid still with the balls singing round me, wondering where they'll hit next" ("The Hospital Lamp" 106). As in Alcott's tale, the protected space of the war hospital is shattered by roar and violence of the war scenes which alternate, in Whitman's "The Veteran's Vision," with the quietude of the hospital which echoes their vivid recollections.

16 Like the one described by Alcott in "The Hospital Lamp," hospital wards are spaces of solidarity that unite injured comrades with bonds of affection: "one of your roughand-readys, Tom was, but underneath as kind as a -well- as a woman" (107), as he help his seriously injured comrade endure many a wakeful hour. Tom helps Absalom survive the horrible pain and trauma of an amputation: a crude procedure which was the most common response to rampant infection and was ruthlessly performed by arrogant surgeons, assisted by compassionate nurses. ${ }^{22}$ Tom later "gets a ball in his throat": a fatal wound reverses his role with Absalom, who eventually stands by his side under the dim but steady light of their comradeship. ${ }^{23}$ And since hospital scenes are forests of Arden where gender reversals occur, Alcott witnesses the sturdiest soldiers cry like babies, softened by a female touch as a substantial part of their cure. The nursing vigil reconfigures that working space, countering the emasculating injuries of defeated soldiers with the rampant masculinization of the female nurses who entered a military scene traditionally denied to women.

\section{Houses Divided and Brotherly Fights}

17 Alcott's accounts of the nursing days in which she was busy mending the many war wounds do not fail to convey her radical perspective on the Civil War. The story of that domestic fight continues in camp hospitals and is critically intertwined with the issues of slavery and mésalliance which originated it. In "My Contraband, or The Brothers," a mulatto confronts his white stepbrother and makes an attempt on his life in a hospital ward, in an indoor slave revolt that Alcott also portrayed in other settings in "M.L." (1860) and in "An Hour" (1864). Appearing in Redpath's abolitionist series, which also included slave biographies and the speeches of Wendell Phillips, the drama of the two brothers fighting in opposite armies reflects the fate of injured prisoners during the conflict. By assuming the domestic rhetoric of Lincoln's abolitionist propaganda in his effort to unite a national home divided by slavery, Alcott defended the brotherly sentiments violated by that conflict, never ignoring the racial tensions produced by the contiguity of contrabands with the wounded rebels who belonged to the same American family. Wounded prisoners were a problem for the medical staff and nurses in hospital wards: the latter being required to protect them from conspiracies and from the sudden physical attacks of hostile visitors and inmates. For this reason, their identity was never revealed to the other patients (Massey 59). The fierce fight between Unionists and Confederates continued in hospital wards, allegorically depicting a divided family whose fighting members dwelled under the same roof: "She saw Confederate soldiers lying side by side with Union men, as kindly treated" ("Love and Loyalty," Camp 238). As war hospitals turned into places where conflicting races and regional rivalries surged, in "The Blue and the Grey," the two brothers' military 
confrontation is dramatized in a stark confrontation of blue jackets and rebels, lying side by side like empty uniforms of different color hanging from the same hook. Thus, the leading metaphor of the rival brothers sharing a divided house turns from Civil War clichés into the melodrama of the siblings raised on the same plantation. As the story "My Contraband" shows, nurses frequently hired mulatto assistants who often happened to be "contrabands," that is, fugitive slaves from the South often brought behind Union lines.

18 When she recovered from her nursing experience, Alcott seriously considered teaching in Port Royal, South Carolina, as she writes in her journal entry of October 1863 (qtd. in Journals, fn 7, 78). Indeed, in their help to indigent families and war orphans, nurses also contributed to the education of slaves from the South. Despite their convinced abolitionism, fugitives and contrabands became a source of anxiety even for convinced New England reformers like Alcott. In this state of racial conflict, the fictionalized encounter of the young nurse from New England with a former slave from the Southern regions was a source of mutual disquiet. The mixed color of mulatto assistants was conventionally associated with low instincts and the illicit attraction of their white fathers who had produced them as illegitimate progeny. As for the Federal hospitals, they were based upon rigid racial and class hierarchies, such that colored workers were mostly employed as cooks and washers, and the highest level that a mulatto could reach was assisting nurses in manual tasks (Massey 370). The violent passions that they seemed to embody are precious ingredients for Nurse Alcott who had been actively at work on anonymous thrillers before the war. Their main features resembled the dark and menacing beauty of the Southern and Cuban protagonists of the Mexican war tales and re-emerged in Alcott's nightmares as tempting seducers, when she broke down, as a result of overwork and unsanitary conditions, with the typhoid fever that obliged her to abandon her nursing appointment. ${ }^{24}$ Alcott's sympathy for contrabands and dusky boys speaks for the writer's life-long fascination with the Spaniard and Indian characters as a woman of Portuguese descent.

19 In her true patriotic spirit, Nurse Alcott did not fail to express her loyalty to the honest and brave Union soldiers whom she often opposes, in a rather Manichean way, to the scheming aristocrats who fight for the Confederates in the South. In "Life in a Pension," a travel story first published in The Independent, November 7, 1867, a family from the American South reports the episode of a Yankee taken prisoner in the South and put under ether to have a shattered arm amputated, while the rebel surgeon takes his leg off, instead, that he might never fight again: "With this sample of Southern chivalry the party broke up, after exchanging photographs and drinking 'Luck to the South"' (Eiselein 182). In reversed conditions, in Hospital Sketches Tribulation Periwinkle contrasts Unionists with Southerners who cowardly attempt murders in wards patrolled by the nurses who, in revenge, humorously adopt with them the same mocking measures introduced in her comic presentation of the tonal variety of her working space:

I regret to say I did not deliver a moral sermon upon the duty of forgiving our enemies [...] then and there; but, being a red-hot Abolitionist, stared fixedly at the tall rebel, who was a copperhead, in every sense of the word, and privately resolved to put soap in his eyes, rub his nose the wrong way, and excoriate his cuticle generally, if I had the washing of him. (32) 
20 In Alcott's treatment, Union soldiers are perhaps less cautious than Southerners in manners, but prove generous with wounded rebels, by performing gestures of "brotherly love and pardon" (316) which result in unexpected conversions. The soldier from Alabama in "The Blue and the Gray, recovers thanks to a zealous Quaker, who finally wins him to her abolitionist cause. As a reign of women and men subjected to physical and emotional constraints, Alcott's war hospital demystifies the general emphasis on war epic and, without diminishing the heroic deeds of the blue jackets, exposes the childish features of wounded soldiers instantly turned into helpless creatures. ${ }^{25}$ Emasculated and tender like the loyal friends in Jean Paul's novels, in those loving hands, born warriors become children made vulnerable by their wounds, and are gently nourished, cuddled, and morally lectured by the maternal nurses who take care of "men, weak and wandering as babies" (42). ${ }^{26}$ The hospital wards run by motherly figures convey the solidarity of friends like Ned and John in Hospital Sketches, under the firm and charitable guide of the matriarch who cures them, as "patients," that is as docile inmates. ${ }^{27}$ In this pseudo-domestic setting, the soldiers' celebrated deeds give way to their comradeship and quietly contribute to peace-making and to the sentimental awareness that real power does not rely on weapons but in love and compassion. In "A Hospital Christmas," Ben learns from the nurses around him the art of dressing wounds and, with "a touch as firm as kind," appears as a man in whom male and female features coexist in harmony, whose gentle manners and determination also defined Alcott's father, Bronson, who subverted the stereotypes of Victorian masculinity. ${ }^{28}$ The force of Christianity exerted by women in wartime (Young, 104) and their ability as nurses and educators to tame "manhood" (104) confirm a subversion of sexual roles in camp hospitals which describes Alcott's own destiny as a nurse, in the suspension of power produced by wartime.

21 Filling the Victorian gap between public and private spheres, in that war emergency medical doctors turn into expert sewers skilled in "little needle-work" (Hospital Sketches 66)and determined women learn their profession.

\section{Late War Tales}

22 The war theme stayed with Alcott for a long time and returned in mid-Seventies New York, in which the writer rediscovered the philanthropic value of her nursing experience while visiting charity and benevolent institutions run by friends. As a convinced advocate of the domestic management of sanitary crises, she reinterpreted her nursing experiences in a series of late Civil War Tales. Thus, in addition to her Hospital Sketches and the collections of war tales written in the aftermath of that conflict, in the mid- and late 1870s she wrote again about brothers fighting in opposite armies and confronted with homely strategies of reform in sanitation and public health that Alcott saw applied in many a benevolent institution in the City. During that 1875 trip, the memory of her nursing service overlapped with the social management of the destitutes experienced by James Gibbons and his wife Abby Hopper, during one of the fiercest financial crises in Victorian America which seemed to reproduce a state of emergency comparable to the one that she faced in wartime. As she visited the unfortunates confined on Blackwell's and Randalls' islands, promptly captured by the graphic illustrations of Gifton, Alcott saw her notions of war nursing employed in philanthropic service, which were applied to the advantage of the public institutions 
aimed to contrast the contagion and chaos produced by the mass migration and the "throng" of impoverished children and women who inhabited the city streets. New forms of domestic management of disease and disorder were required, and the pale, insomniac Alcott wrote a veteran's story, "The Romance of a Summer Day" (1872) (rpt. in Silver Pitchers and Independence 102-35), collected in a volume devoted to the issue of benevolence and of the general "protest against wine-drinking" (6). The story of a mutilated boatman who takes tourists across the river for a small fee is another story of war friendship in which a soldier places his comrade next to his mother after his fatal deeds. The title of the collection of stories echoed Rebecca Harding Davis's novel Earthen Pitchers, serialized in Scribner's Monthly in 1873 and 1874, on women not conventionally beautiful who made a living in a time of social emergency, contributing to revolutionize aesthetic standards and the realistic rhetoric adopted to cast light on the philathropic work of women in flesh and blood.

23 In the era of Reconstruction in which Alcott seemed to have lost the ardor and intensity of her early experiments, she celebrated the little known heroines of the American Revolution like Tabitha Taball in a tale published in St. Nicholas in 1884. Her literary work seemed mostly aimed at children's entertainment, as her readers apparently required. As the centennial anniversary of Independence approached, Alcott's combative spirit resurfaced and reacted to the public dismissal of women in the celebration of American Independence. The city of Concord had sadly forgotten the female descendants of the heroes of the American Revolution, who gathered at the North Bridge, where their ancestors dared challenge the British troops. Too anxious to celebrate their brave men, Concord's administrators forgot "to glorify our foremothers" ("Tabby's Table-Cloth," Spinning-Wheel Stories 27) and this resulted in a tragic-comic account which appeared on May 1, 1875 in the Woman's Journal. The story of the Concord woman who became a spy and a messenger in 1775 also showed how women could fight for their country without using male violence. In an example of female astuteness and domestic heroism, Tabby hides the patriots' messages in egg baskets, their guns in flour's heaps and feather mattresses, and prevents the attack of British troops by hiding under a tablecloth and eavesdropping on the conversation of a British general with a Tory spy. "I can't fight, but I must see," she would later explain (37). After that war, the table-cloth which had served her as a hiding place is used again to celebrate Christmas and her sons' weddings and baptisms. And as the Civil War starts, Tabby is a grandmother determined to make bandages and supplies for the wounded soldiers out of that glorious table-cloth, in a patriotic recycling aimed to cure the soldiers. Thus, the precious item and relic from the American Revolution is used again to dress wounds, thanks to a female practical sense which knew how to respond to the urgency of the moment and to the empty rhetoric of the anniversaries, in hard times of scarcity "when patience ceased to be a virtue and rebellion was just" (37).

The war theme stayed with Alcott for a long time and returned in mid-Seventies New York, in which the writer rediscovered the philanthropic value of her nursing experience while visiting charity and benevolent institutions run by friends. In the relative stability of the Reconstruction era, her retrospective war adventures had very little of the enthusiasm and urgency of Tribulation's accounts of the Civil war crisis. Nevertheless, they served to celebrate her proud generation of matronly reformers who played an unsurpassed leading role in the innovation of healing practices. Their domestic management of disease and disorder served to redefine medical hierarchies 
and sanitary strategies that were promptly appropriated by the growing army of charitable ladies bravely confronting the new social emergencies brought about by the widespread bankruptcies and financial crises that cyclically accompanied the urban growth of post-bellum America.

\section{BIBLIOGRAPHY}

Alcott, Louisa May. Hospital Sketches (1863). Bedford, Mass.: Applewood, 1993. Print.

---. Little Women (1868-69). Works by Louisa May Alcott. Ed. Claire Booss. New York: Avenel, 1983. Print.

---. Hospital Sketches and Camp and Fireside Stories. Boston: Roberts Brothers, 1869. Print.

---. Silver Pitchers: and Independence. A Centennial Love Story. Boston: Roberts, 1876. Print.

---. Spinning-Wheel Stories, Boston: Little Brown \& Co, 1884. Print.

Brown, Thomas J. Dorothea Dix: New England Reformer. Cambridge, MA: Harvard UP, 1998. Print.

Dall, Caroline H. Women's Right to Labour or, Low Wages and Hard Work. Boston: Walker, Wise, 1860. Print.

Douglas, Ann. "The War Within a War: Women Nurses in the Union Army." Civil War History 6.198 (Sept. 1972): 197-212. Print.

---. The Feminization of American Culture. New York: Avon, 1977. Print.

Eiselein,Gregory. The Sketches of Louisa May Alcott. New York, Ironweed Press, 2011. Print.

Elbert,Sarah, ed. Louisa May Alcott on Race, Sex and Slavery. Boston: Northeastern UP, 1997. Print.

Kaser, David. Books and Librares in Camp and Battle: The Civil War. Westport, CT: Greenwood Press, 1984. Print.

Matthews,Joshua. "Walt Whitman's Vision of the Inferno, or Dante in Drum-Taps.”Walt Whitman Quarterly Review 32 (2014): 36-68. Print.

Massey, Mary Elizabeth. Women in the Civil War. Lincoln: Nebraska U , 1966. Print.

Myerson,Joel, Daniel Shealy, and Madeleine B. Stern, eds. The Selected Letters of Louisa May Alcott. Athens: Georgia UP, 1987. Print.

Myerson, Joel, and Daniele Shealy, eds. The Journals of Louisa May Alcott. Introd. Madeleine B. Stern. New York: Little Brown, 1989. Print.

Nightingale, Florence. Notes on Nursing. What It Is and What It is Not. 1860. New York: Dover, 1969. Print.

Pollard, Eliza F. Florence Nightingale: The Wounded Soldier's Friend. London: S. W. Partridge, 1899. Print.

Reverby, Susan Ordered to Care: The Dilemma of American Nursing, 1850-1945. Cambridge, MA: Cambridge UP, 1987. Print. 
Schultz, Jane E. “The Inhospitable Hospital: Gender and professionalism in Civil War Medicine." Signs (Winter 1992): 363-92. Print.

Showalter, Elaine, ed. Alternative Alcott. New Brunswick: Rutgers UP, 1988. Print.

Sussman, Herbert. Victorian Masculinities: Manhood and Masculine Politics in Early Victorian Literature and Art. Cambridge, MA: Cambridge UP, 1995. Print.

Thomas, Clara. Love and Work Enough: The Life of Anna Jameson.Toronto: Toronto UP, 1967. Print.

Ticknor, Caroline. May Alcott: A Memoir. Boston: Little Brown, 1928. Print.

Young, Elizabeth. Disarming the Nation: Women's Writing and the American Civil War. Chicago:

Chicago U P, 1999. Print.

\section{NOTES}

1. "Mr Alcott says he sends his only son. Louisa is determined to make the soldiers jolly, and takes all of Dickens that she has, and games" (qtd. in Ticknor 54). On December 12, 1862, Louisa Alcott, whose tireless energy had made it "impossible for her to sit at home while she felt that her country needed her, began her career as a war nurse [...] just at last, her courage almost failed her, and she embraced her mother crying, 'Shall I stay?' To which Mrs Alcott answered through her tears, 'No, go! and Lord be with you"' (qtd. in Ticknor 55).

2. "On the $21^{\text {st }}$ I suddenly decided to go home, feeling very strangely \& dreading the worse. Mrs Ropes died \& that frightened the Drs about me for my trouble was the same typhoid pneumonia [...] Miss Dix brought a basket full of bottles of mine, tea, medicine, \& cologne, beside a little blanket \& pillow, a fan \& a Testament. She is a kind soul but very fussy [crossed out] queer \& arbitrary, no one likes her \& I dont wonder [crossed out]." Louisa May Alcott, diary of January 16, 1863 (Houghton Library's manuscript, Harvard University).

3. "The organization of a training school is and must be military. It is not and cannot be democratic [...] to this end complete subordination of the individual to the world as a whole is necessary for her as a soldier." Lavinia Dock, "The Relation of Training Schools to Hospitals," qtd. in Reverby53.

4. "[...] the heroic lad had been more successful in the service of Commander-in-Chief Cupid than that of Gen. Mars; and a charming little romance blossomed instantly in Nurse Periwinkle's romantic fancy" (Hospital Sketches 38 ).

5. "What right have I to think of my happiness when my country needs me? It is like deserting my old mother in extremest peril to stand idle now" ("Love and Loyalty," Camp 199).

6. "[...] to scrub some dozen lords of creation at a moment's notice, was really - really -. However, there was no time for nonsense, and, having resolved when I came to do everything I was bid, I drowned my scruples in my washbowl, clutched my soap manfully, and, assuming a businesslike air, made a dab at the first dirty specimen I saw, bent on performing my task vi et armis (trans: by force of arms) if necessary" (Hospital Sketches 23).

7. In May 19, 186[3], Alcott wrote to Thomas Wentworth Higginson who led the first authorized regiment in the Union army that she was determined to get involved in the 1st South Carolina volunteers: "Dont you want a cook, a nurse, or somewhat venerable 'Child' for your regiment? I am willing to enlist in any capacity for the blood of old Col. May asserts itself in his granddaughter in these martial times \& she is very anxious to be busied in some more loyal labor than sitting quietly at home spinning fictions" (The Selected Letters 96-97).

8. As Thomas Brown points out: "military physicians opposed the introduction of women nurses with a vehemence that far exceeded the ordinary contempt of career Army officers toward all 
volunteer relief efforts. Wood, a cautious administrator eager to advance within the Medical Department, expressed the doctors' hostility adroitly in discharging his obligation to work with Dix. He tried to use her appointment to minimize the number of women volunteers and isolate them from the medical bureau" (281).

9. Among them, it is worth listing Dorothea Dix, Virginia Penny, Mrs. Jane Hoge, Mrs. Mary Ashton Livermore, widow Mary Ann Bickerdyke, Eliza Porter, and Caroline H. Dall who sustained the publication of Louisa May Alcott's first novel for adults, Moods (1864).

10. Tribulation recalls: "The doctors paid daily visits, tapped at my lungs to see if pneumonia was within, left doses without names, and went away, leaving me as ignorant, and much more uncomfortable than when they came" (Hospital Sketches 77).

11. "Like a flock of friendly ravens, my sister nurses fed me, not only with food for the body, but with kind words for the mind [...] and among her relics of that Washington defeat, none is more valued than the little book which appeared on her pillow, one dreary day; for the D D. written in it means to her far more than Doctor of Divinity" (70-71).

12. Hale recommended Meditations on Private Hours (1928) in the inaugural issue of The Pearl. Other neglected stories by Dix areTen Short Stories for Children (1827), The Pearl, a Christmas Gift and A Garland of Flora, both published in 1829. The latter title echoes Alcott's early Flower Fables (1854).

13. They compared notes on medical institutions, developing a coherent vision of nursing as a female Protestant vocation nourished by the theories of British reformers whose activities they followed on non-medical institutions such as the insane asylums in England (Brown 267).

14. "[...] owing to the stupidity of that mysterious 'somebody' who does all the damage in the world, the windows had been carefully nailed down above" (Hospital Sketches 41).

15. "Much of the Roman matron's courage had gone into the Yankee matron's composition, and, in spite of her tears, she would have sent ten sons to the war, had she possessed them" (3).

16. Nurse Periwinkle thus describes them: "I took my first lesson in the art of dressing wounds. It wasn't a festive scene, by any means; for Dr. P., whose Aid I constituted myself, fell to work with a vigor which soon convinced me that I was a weaker vessel, though nothing would have induced me to confess that. He had served in Crimea, and seemed to regard a dilapidated body very much as I should have regarded a damaged garment; and turning up his cuffs, whipped out a very unpleasant looking housewife, cutting, sawing, patching and piercing, with the enthusiasm of an accomplished surgical seamstress; explaining the process, in scientific terms, to the patient, meantime; which, of course was immensely cheering and comfortable" (36).

17. In their diaries, letters and biographies, nurses often reported how wounded patients did not merely need food and medicines, but the therapeutic power of a woman's presence and touch (Douglas, "The War within a War" 200, 212).

18. "I usually found my boys in the jolliest state of mind their conditions allowed; for it was a known fact that Nurse Periwinkle objected to blue devils, and entertained a belief that he who laughed most was surest of recovery. At the beginning of my reign, dumps and dismals prevailed; the nurses looked anxious and tired, the men gloomy or sad; and a general 'Haark! -from-thetombs-a-doleful-sound' style of conversation seemed to be the fashion: a state of things which caused one coming from a merry, social New England town, to feel as if she had got into an exhausted receiver; and the instinct of self-preservation, to say nothing of a philanthropic desire to serve the race, caused a speedy change in Ward No. 1" (Hospital Sketches 40).

19. "The Sergeant also originated, I believe, the fashion of calling his neighbors by their afflictions instead of their names; and I was rather taken aback by hearing them bandy remarks of this sort, with perfect good humor and much enjoyment of the new game. 'Hallo, old Fits is off again!' 'How are you, Rheumatiz?' 'Will you trade apples, Ribs?' 'I say, Miss P., may I give Typhus a drink of this?' 'Look here, No Toes lend us a stamp, there's a good feller,' etc. He himself was christened 'Baby B.,' because he tended his arm on a little pillow, and called it his infant" (88). 
20. Initially published with the title "The Brothers" in the Atlantic Monthly 12.73 (Nov. 1863), this tale was later reprinted in Hospital Sketches and Camp and Fireside Stories and, more recently, in Louisa May Alcott on Race, Sex, and Slavery 69-86 and in Alternative Alcott 74-95.

21. "The Hospital Lamp" first appeared in The Daily Morning Drum-Beat, Feb. 24 and 25, 1864, and was rpt. in The Sketches 103-111.

22. "The mere memory of it made him quiver and shut his eyes, as if he felt again the sharp agony of shattered bones, rent flesh, and pitiless knife [...] It seemed as if he was cutting my heart out, and I never could have stood it if it hadn't been for Tom. He held me close and steady, but he cried like a baby the whole time, and that did me good. Can't say why, but he did [...] Tom's face wet and white, the surgeon with his red hands, swearing to himself as he worked, and all the while such a roar of guns in my ears I hardly heard myself crying out for someone to shoot me and put me out of my misery" ("The Hospital Lamp" 108).

23. "I hadn't any folks of my own. Tom had -wife, children, father, mother, brothers and sisters, and lots of friends of everywhere [...].There is was, sitting as I left him, his hand on my pillar, his face turned toward me so quiet looking and so happy I couldn't believe he was gone [...] underneath his forbidding exterior he hid so much of the genuine tenderness which few men are without. Now I had found the clue to these wakeful hours of his and the love he bore the lamp whose little flame had lighted him to a clearer knowledge of himself [...] in his rough brown face the tranquil expression of a tired child" ("The Hospital Lamp" 109-10).

24. "A I never shall forget the strange fancies that haunted me I shall amuse myself with recording some of them. The most vivid \& enduring was a conviction that I had married a stout, handsome Spaniard, dressed in black velvet with very soft hands \& a voice that was continually saying, "Lie still, my dear." This was mother, I suspect, with all the comfort I often found in her presence there was blended an awful fear of the Spanish spouse who was always coming after me, appearing out of closets, in at windows, or threatening me dreadfully all night long" (Jan. 1863, Journals 116).

25. "I'm so tired I just wish I could die and be out of this misery,' sobbed the poor ghost of a once strong and cheery fellow, as the kind hand wiped his tears away, and gently rubbed the weary shoulders" ("A Hospital Christmas" 322).

26. Tribulation helps feed them: "As I fed my big nestling with corresponding mouthfuls, I asked him how he felt during the battle" (Hospital Sketches 34 ).

27. "It is all very well to talk of the patience of woman [...] the patient endurance of these men, under trials of the flesh, was truly wonderful" (37).

28. "Patient, strong, and tender, he seemed to combine many of the best traits of both man and woman; for he appeared to know by instinct where the soft spot was to be found in every heart, and how best to help sick body or sad soul" ("A Hospital Christmas," Camp 325-26).

\section{ABSTRACTS}

Louisa May Alcott's literary career started with a humorous account of her nursing experience in the Union Army. The Civil War remained a major theme even in the tales that she wrote during the Reconstruction Era. They celebrate the professional achievements of sturdy "deaconesses" like Dorothea Dix, who rapidly turned the dilapidated sanitary system of a divided nation into a domestic order restored by female healing powers. 
INDEX

Mots-clés: Bronson Alcott, Caroline Dall, Charles Dickens, Dorothea L. Dix, Faith Dane, Florence Nightingale, Jean Paul, Proper Names: Louisa May Alcott, Thomas Wentworth Higginson, Tribulation Periwinkle, Walt Whitman

Keywords: Civil War; Louisa May Alcott; War Nursing in American literature; Dorothea Dix

\section{AUTHOR}

\section{DANIELA DANIELE}

DILE Università di Udine, via Mantica, 33100 UDINE (Italy); danadaniele@libero.it 